\title{
External Corrosion Analysis of Model 9975 Packaging Container
}

by

P. Vormelker

Westinghouse Savannah River Company

Savannah River Site

Aiken, South Carolina 29808

DOE Contract No. DE-AC09-96SR18500

This paper was prepared in connection with work done under the above contract number with the U. S.

Department of Energy. By acceptance of this paper, the publisher and/or recipient acknowledges the U.S. Government's right to retain a nonexclusive, royalty-free license in and to any copyright covering this paper, along with the right to reproduce and to authorize others to reproduce all or part of the copyrighted paper. 
Keywords: Model 9975 Packaging KAMS

Corrosion

External

Stainless Steel

Retention: Permanent

\title{
EXTERNAL CORROSION ANALYSIS OF MODEL 9975 PACKAGING CONTAINER (U)
}

\author{
Philip R. Vormelker \\ Savannah River Technology Center \\ Strategic Materials Technology Department \\ Materials Technology Section \\ Materials Consultation Group
}

Publication Date: January 1999

\section{DOES NOT CONTAIN \\ UNCLASSIFIED CONTROLLED \\ NUCLEAR INFORMATION}

ADC \&

Reviewing

Official:

Date:

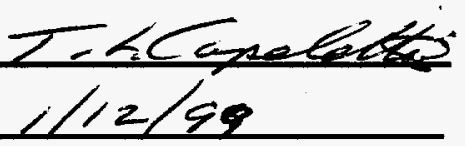

Westinghouse Savannah River Company

Savannah River Site

Aiken, SC 29808

This document was prepared in connection with work done under Contract No. DE-AC09-96SR 18500

with the U. S. Department of Energy 


\section{DISCLAIMER}

This report was prepared as an account of work sponsored by an agency of the United States Government. Neither the United States Government nor any agency thereof, nor any of their employees, makes any warranty, express or implied, or assumes any legal liability or responsibility for the accuracy, completeness, or usefulness of any information, apparatus, product, or process disclosed, or represents that its use would not infringe privately owned rights. Reference herein to any specific commercial product, process, or service by trade name, trademark, manufacturer, or otherwise does not necessarily constitute or imply its endorsement, recommendation, or favoring by the United States Government or any agency thereof. The views and opinions of authors expressed herein do not necessarily state or reflect those of the United States Government or any agency thereof.

This report has been reproduced directly from the best available copy.

Available to DOE and DOE contractors from the Office of Scientific and Technical Information, P.O. Box 62, Oak Ridge, TN 37831; prices available from (615) 576-8401.

Available to the public from the National Technical Information Service, U.S. Department of Commerce; 5285 Port Royal Road, Springfield, VA 22161. 


\section{DISCLAIMER}

Portions of this document may be illegible in electronic image products. Images are produced from the best available original document. 
DOCUMENT: WSRC-TR-98-00454

TITLE: $\quad$ EXTERNAL CORROSION ANALYSIS OF MODEL 9975 PACKAGING CONTAINER (U)

TASK: $\quad$ SRT-PTG-98-8007

\section{APPROVALS}

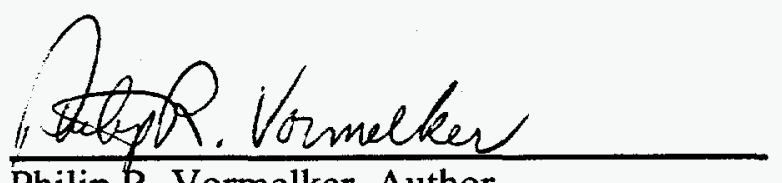

Date: $1 / 11 / 99$

Philip R. Vormelker, Author

Materials Consultation Group

MATERIALS TECHNOLOGY SECTION

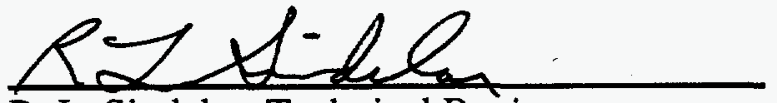

R. L. Sindelar, Technical Reviewer

Date: $1 / 12 / 99$

Materials Application and Corrosion Technology Group

MATERIALS TECHNOLOGY SECTION

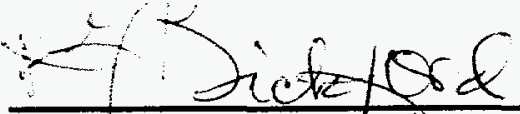

R. Linnea Bickford, Manager

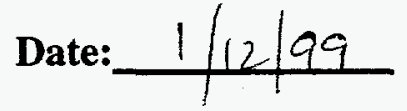

Materials Consultation Group

MATERIALS TECHNOLOGY SECTION

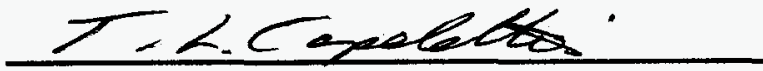

Tami L. Capeletti, Manager

MATERIALS TECHNOLOGY SECTION

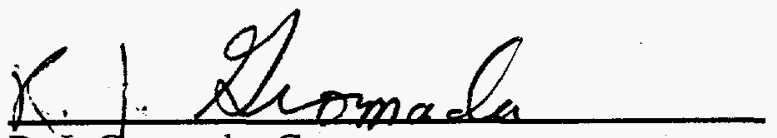

R. J. Gromada, Customer

Date: $1 / 14 / 99$

Packaging and Transportation Group

ENGINEERED EQUIPMENT AND SYSTEMS DEPARTMENT

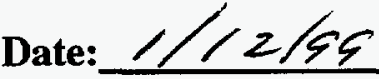




\section{TABLE OF CONTENTS}

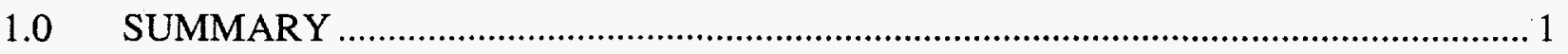

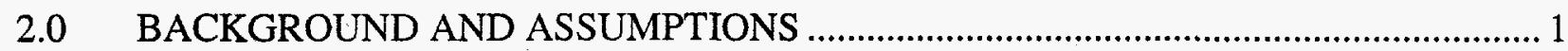

EXTERNAL CORROSION ANALYSIS ............................................

3.1 External Corrosion Analysis of Model 9975 Outer Container........................ 1

3.2 Other Corrosion Concerns.......................................................... 3

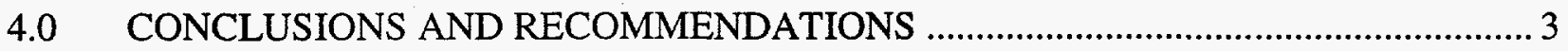

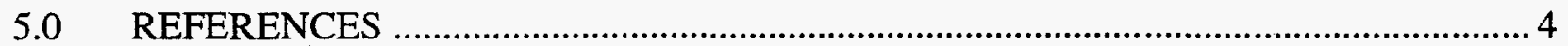




\section{LIST OF FIGURES}

Figure 1. Overall Schematic of the Model 9975 Packaging Assembly ........................................ 5

Figure 2. Author's Conception of Placement of Five 9975 Drums on Galvanized Steel Pallet....6

\section{LIST OF TABLES}

Table 1. Corrosion of AISI 300-Series Stainless Steels in a Marine Atmosphere 7

Table 2. Atmospheric Corrosion of Stainless Steels at Two Industrial Sites .7

\section{LIST OF ABBREVIATIONS}

ASTM American Society for Testing and Materials

ASME American Society of Mechanical Engineers

RFETS Rocky Flats Environmental Technology Site

SARP Safety Analysis Report for Packaging

SRS Savannah River Site

SRTC Savannah River Technology Center

SS Stainless Steel 


\subsection{SUMMARY}

The Materials Consultation Group of SRTC has completed an external corrosion analysis of the Model 9975 packaging container for storage in K Reactor under ambient conditions for a period of 12 years. The 12-year storage period includes two years for shipping and ten years for storage. Based on review of existing literature and stated building storage conditions, corrosion degradation of the 304L Stainless Steel (SS) packaging containers (drum and vessels) should be minimal during the 12 year time period. There may be visible corrosion on the galvanized carbon steel pallet due to initial drum handling. The visible corrosion will not be sufficient to cause significant degradation during the 12-year storage period. The Materials Consultation Group concludes that there are sufficient data to establish the technical basis for safe storage of the Model 9975 container in the $105-\mathrm{K}$ building for up to 10 years following the 2-year shipping period. The data are sufficient to allow the $304 \mathrm{~L} \mathrm{SS}$ containers to be stored for a total period of 15 years.

\subsection{BACKGROUND AND ASSUMPTIONS}

Pu-bearing materials (metal and oxides) currently stored at RFETS (Rocky Flats Environmental Technology Site) are to be shipped to SRS in Model 9975 packaging assemblies for interim storage prior to future disposition. Multiple units of the Model 9975 packaging assembly will be strapped to a galvanized steel pallet. The outer container in the Model 9975 is composed of a welded SS 35-gallon drum per Figure 1. The welded drum is constructed of 304L SS with 308L SS filler material. ${ }^{1,2}$ The wall, lid, and bottom of the drum will be of 18 gauge ( 0.048 inches) material. The drum will have a 304L SS identification plate that will be tack welded and then caulked around the top and side edges with a silicone rubber sealant (Dow Corning 732 RTV or equivalent). ${ }^{1}$ The SRS total chlorine limit for materials in contact with SS, such as a caulking compound, is $250 \mathrm{ppm} .{ }^{3}$ The Primary and Secondary Containment Vessels are also constructed of $304 \mathrm{~L} \mathrm{SS}$.

A maximum of five drums will be strapped together on one galvanized carbon steel pallet similar to Figure $2 .{ }^{4}$ A second pallet will be stacked on top of the first one. The stacking limit is two pallets high. ${ }^{4}$

Upon arrival at SRS, the 9975 packaging assemblies will be stored in Building 105-K process room, crane maintenance area, stack area, and the crane wash area. The building environment will essentially mimic outdoor weather patterns except that the assemblies will be shielded from wind, rain, and storms. Temperatures will range from $0^{\circ} \mathrm{F}$ to $130^{\circ} \mathrm{F}\left(-18^{\circ} \mathrm{C}\right.$ to $\left.54^{\circ} \mathrm{C}\right)$ with varying humidity levels up to $100 \%{ }^{5}$ The building will be heated but not cooled.

\subsection{EXTERNAL CORROSION ANALYSIS}

\subsection{External Corrosion Analysis of Model 9975 Outer Container}

Austenitic SS is generally a very corrosion resistant material in most environments. The composition of $304 \mathrm{SS}$ is approximately 18-20\% chromium, 8-12\% nickel, $2 \%$ manganese and $0.08 \%$ carbon with limited amounts of phosphorus, sulfur, silicon, and nitrogen. The chromium 
creates an oxide film that protects the material in oxidizing conditions while nickel aids in protecting the material in reducing conditions. Thus, 304 SS shows resistance to both nitric and sulfuric acids. The L-grade reduces the carbon levels to $0.03 \%$ or less to prevent sensitization (precipitation of chromium carbides) during exposure to heating above $800^{\circ} \mathrm{F}$. However, the elemental composition of $304 \mathrm{~L}$ SS does not prevent stress corrosion cracking from occurring due to chloride exposure. The excellent atmospheric corrosion resistance of 304 SS is a very important consideration for use in storage conditions.

While stainless steel's corrosion resistance to building storage conditions has not been found in the literature, exposure to industrial and marine atmospheres is available. Humidity, air temperatures, type of industrial pollution, vicinity to marine exposure, mating of dissimilar materials, and fabrication type influence the behavior of austenitic stainless steel in these atmospheres. The SRS atmosphere tends to be more rural since the site is distant from the more populated and industrial areas. Although the Model 9975 shipping container will be sheltered, data from industrial and/or marine exposure should be a worst case scenario for the 304L SS container. Table 1 contains marine exposure data $(250 \mathrm{~m}$ from the ocean) for a 15-year exposure of austenitic stainless steel samples. ${ }^{6}$ The 304 SS samples were found to be spotted with a slight rust stain on $15 \%$ of the sample surface with an average pit depth of 1.1 mils $(0.028$ $\mathrm{mm}$ ). The maximum average pit depth for all the austenitic stainless steel samples was 1.6 mils $(0.04 \mathrm{~mm})$. Data was not available on maximum pit depths. General corrosion of each of the austenitic stainless steels in the marine atmosphere was less than 0.001 mils per year or less than $0.015 \times 10^{-3}$ inches $\left(3.8 \times 10^{-4} \mathrm{~mm}\right)$ for the 15 -year testing period. While the rust stain is probably due to films of soot and dirt containing iron, pitting is due to the presence of chlorides.

In Table 2, the difference in two city atmospheres shows definite effects from chlorides. While samples exposed to the atmosphere in New York City for 26 years showed no rust staining, samples exposed in Niagara Falls near industrial plants producing chlorine and hydrochloric acid were attacked in less than a year. ${ }^{7}$ Assuming that the atmospheric level of chlorides around SRS. is more similar to New York, then it is to Niagara Falls, a conservative value of 3.2 mils $(0.08$ $\mathrm{mm}$ ) will be used as the maximum expected pit depth for the $105-\mathrm{K}$ storage atmosphere over the 12 -year period. This value is double that of the maximum average pit depth in Table 1 . This maximum pit depth (0.0032 inches) is approximately $7 \%$ of the thickness (0.048 inches) of the Model 9975 container. The maximum pit depth is also within the permissible variation in sheet thickness of \pm 0.005 inches from manufacturing per ASTM standards. ${ }^{8}$ Also, the maximum general corrosion rate of the Model 9975 container is expected to be less than $0.015 \times 10^{-3}$ inches based on the previously mentioned marine data for a 15 -year period. Thus, very little corrosion (general and pitting) is expected on the 9975 outer shipping container during storage conditions in Building 105-K.

Intergranular and transgranular stress corrosion cracking of the welded areas of the Model 9975 container is not expected due to fabrication with annealed, low carbon $304 \mathrm{SS}$ (304L) and the lack of chlorides in the $105-\mathrm{K}$ building environment, respectively. The low carbon content in 304L SS limits precipitation of carbides in the grain boundaries during welding that provides intergranular stress corrosion cracking resistance. Elimination of chloride containing cleaning agents in the drum storage area precludes the potential for transgranular stress corrosion cracking. 


\subsection{Other Corrosion Concerns}

The identification plate will be caulked on sides and top per the 9972-9975 Series Packagings drawing. ${ }^{1}$ Caulking is not specified for use on the bottom edge. The caulking is specified as Dow Corning 732 RTV or equivalent. Various 304 SS stress corrosion cracking incidents have occurred in the past at SRS due to chloride bearing labels. To prevent this, a SRS chloride limit of $250 \mathrm{ppm}$, maximum, is used for any material in contact with SS. ${ }^{3}$ The Materials Consultation Group maintains a chloride database based on incoming materials being analyzed. Normally, silicones do not contain significant chlorides. One version of Dow Corning's RTV caulking (3145 RTV) was analyzed to have $11 \mathrm{ppm}$ chloride. However, the current Materials Consultation Group chloride database (1993-1998) does not contain test results for Dow Corning's $732 \mathrm{RTV}$ over the last 5 years. It is suggested that the $732 \mathrm{RTV}$ or equivalent be tested for chlorides.

A galvanized carbon steel pallet is normally expected to last a long time, even in exterior applications. However, corrosion of zinc will increase with increasing moisture levels (primarily acid rain). Reference 9 discusses interior applications of hot dip galvanized steel and states that it can be used in wet (high humidity) interior applications for up to 20 years before any maintenance is required. A typical application in this environment is structural steel. One caveat is that this assumes that no penetrations or pinholes exist in the zinc coating. Exposed carbon steel, due to small pinholes in the zinc coating, will not corrode due to cathodic protection. When large through coating penetrations are made, such as a scratch from a drum being scraped against the coating, the exposed area of the carbon steel may be too large to be cathodically protected. This produces surface corrosion in the carbon steel that will be a visual defect. If the visual defects become a housekeeping problem, maintenance may be required. This will not cause significant structural degradation to the carbon steel pallet over the 12-year period.

Galvanized and painted carbon steel strapping is subject to corrosion during service to bind drums on a pallet. Rust stains have been observed (by the author) on $\mathrm{D}_{2} \mathrm{O}$ drums (stainless steel) due to corrosion of the galvanized strapping. The drums were stored in the crane maintenance area of 105-K. Condensate will cause corrosion on existing breaks in the strapping coating and will drip on the stainless steel drum. It is very difficult for a coating to survive the tension, twisting, rubbing, and bending of strapping installation without a coating break. This is another visual appearance problem. Stainless steel strapping should behave in the same manner as the 304L SS outer container in the Model 9975 shipping assembly discussed previously. Stainless steel is the recommended material for strapping in this application.

Based on a review of available data relative to the long-term performance of 304L SS, the Model 9975 outer container is not expected to develop significant corrosion degradation during the total time of 12 years. It is recommended that the specific silicon sealant or equivalent be tested for chloride levels prior to use. Corrosion of the galvanized steel pallet is expected to create a visual appearance problem during the storage period. Stainless steel strapping is also recommended to prevent visual appearance problems on the strapping and the Model 9975 outer container. 


\subsection{REFERENCES}

1) United States Department Of Energy Savannah River Site Drawing Number R-R2-F0006 Revision 2, "9972-9975 Series Packagings - Drum Assemblies (U)," July 7, 1997.

2) ASME Boiler and Pressure Vessel Code, Section II Materials Part A - Ferrous Material Specifications, SA-240 Type 304L, "Specification for Heat-Resisting Chromium and Chromium-Nickel Stainless Steel Plate, Sheet, and Strip for Pressure Vessels," 1995.

3) SRS Engineering Standard No. 05952 Rev. 0, "Practices To Minimize Chloride Induced Stress Corrosion Cracking Of Type 300 Series Austenitic Stainless Steel," (SRS Engineering Standards Manual: WSRC-TM-95-1) August 1, 1995.

4) Memo, T. D. Woodsmall to A. J. Cappucci, SRS-RPS-98-0116 Rev. 0, "KAMS Safety Analysis for Container Qualification Inputs and Assumptions (U)," September 13, 1998.

5) Tharakan, B. K, WSMS Calculation: S-CLC-K-00145 Rev. A, "Fire Accident Analysis Report," October 28, 1998.

6) Literature, Corrosion Resistance of the Austenitic Chromium-Nickel Stainless Steels in Atmospheric Environments, The International Nickel Company, Inc., 1963

7) ASM Metals Handbook, Ninth Edition, Volume 13, "Corrosion" (ASM International, Metals Park, Ohio, September 1987) p 554.

8) ASTM Standards, A-480, Standard Specification for General Requirements for FlatRolled Stainless and Heat-Resisting Steel Plate, Sheet, and Strip," (ASTM, Philadelphia, PA, 1994).

9) British Standard BS5493, "Protection Systems" (British Standards Institution, London, UK, 1977) per F. C. Porter, "Corrosion Resistance of Zinc and Zinc Alloys" (Marcel Dekker, 1994) p. 178-179.

Acknowledgements

The author appreciates the timely assistance from Susan Issacs of 773-A Library Services. 


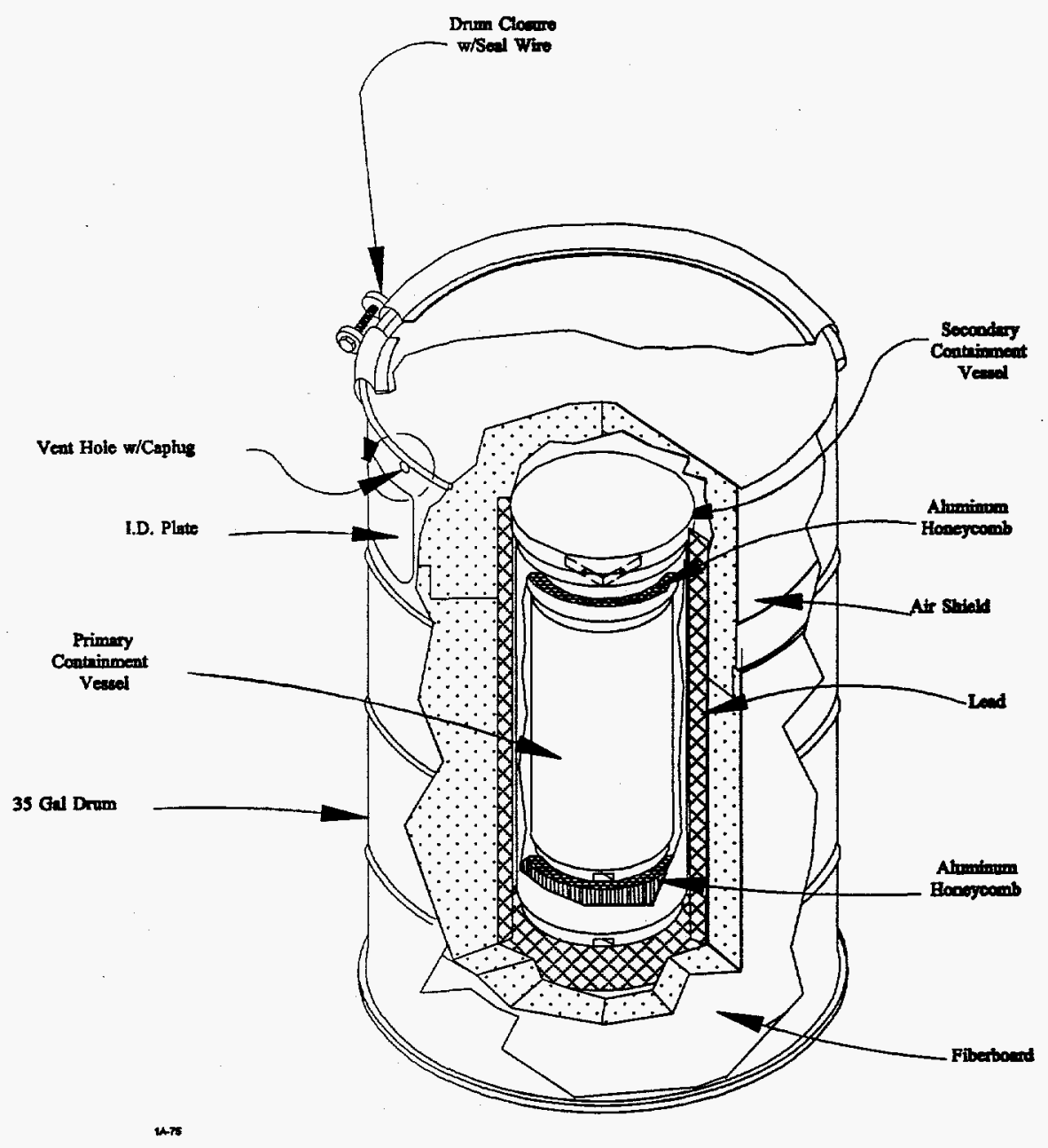

Figure 1. Overall Schematic of the Model 9975 Packaging Assembly [1]. 


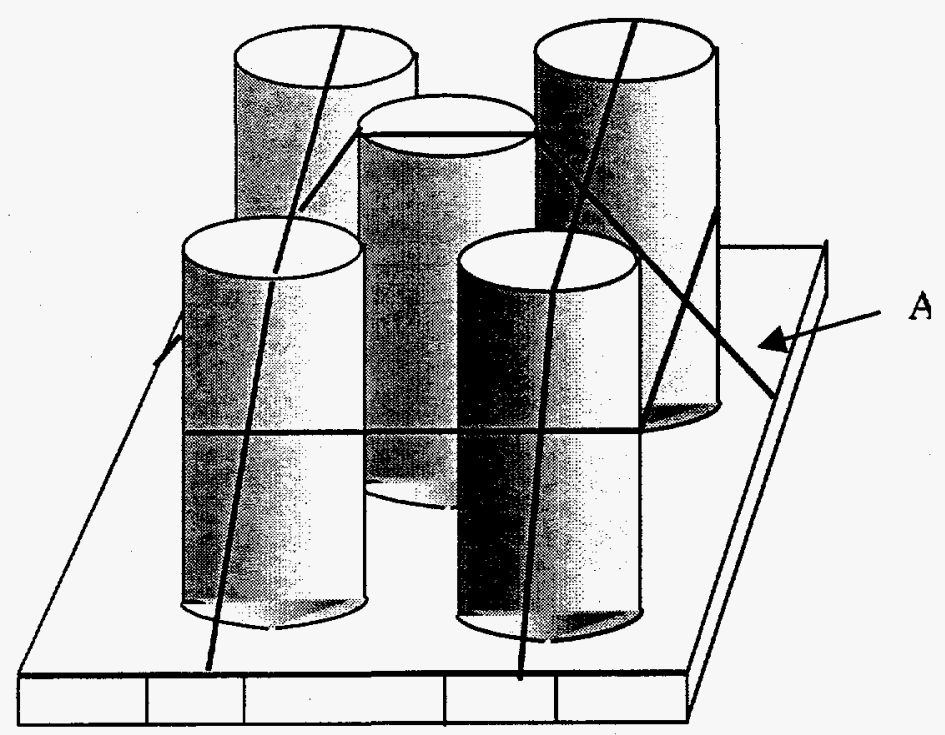

Figure 2 Author's conception of placement of five 9975 drums on galvanized steel pallet. Note strapping (A) securing drums to pallet. Pallet size is 4 feet by 4 feet. Drawing is not to scale. 
Table 1. Corrosion of AISI 300-Series Stainless Steels in a marine atmosphere ${ }^{6}$ (Based on 15-year exposures $250 \mathrm{~m}$ ( $800 \mathrm{ft}$.) from the ocean at Kure Beach, NC)

\begin{tabular}{|c|c|c|c|c|c|}
\hline AISI & Average Cor & osion Rate & Avera & f Pits & \\
\hline Type & $\mathrm{mm} / \mathrm{yr}$ & mils/yr & $\mathrm{mm}$ & mils & Appearance (a) \\
\hline 301 & $<2.5 \times 10-5$ & $<0.001$ & 0.04 & 1.6 & $\begin{array}{l}\text { Light rust and rust stain on } \\
20 \% \text { of surface }\end{array}$ \\
\hline 302 & $<2.5 \times 10-5$ & $<0.001$ & 0.03 & 1.2 & $\begin{array}{l}\text { Spotted with rust stain on } \\
10 \% \text { of surface }\end{array}$ \\
\hline 304 & $<2.5 \times 10-5$ & $<0.001$ & 0.028 & 1.1 & $\begin{array}{l}\text { Spotted with slight rust stain } \\
\text { on } 15 \% \text { of surface }\end{array}$ \\
\hline 308 & $<2.5 \times 10-5$ & $<0.001$ & 0.04 & 1.6 & $\begin{array}{l}\text { spotted by rust stain on } \\
25 \% \text { of surface }\end{array}$ \\
\hline 316 & $<2.5 \times 10-5$ & $<0.001$ & 0.025 & 1.0 & $\begin{array}{l}\text { Extremely slight rust stain } \\
\text { on } 15 \% \text { of surface }\end{array}$ \\
\hline 317 & $<2.5 \times 10-5$ & $<0.001$ & 0.028 & 1.1 & $\begin{array}{l}\text { Extremely slight rust stain } \\
\text { on } 20 \% \text { of surface }\end{array}$ \\
\hline
\end{tabular}

(a) All stains easily removed to reveal bright surface

Table 2. Atmospheric Corrosion of Stainless Steels at Two Industrial Sites ${ }^{7}$

\begin{tabular}{|c|c|c|c|c|}
\hline \multirow[b]{2}{*}{ Type (a) } & \multicolumn{2}{|c|}{ New York City (industrial) } & \multicolumn{2}{|c|}{ Niagara Falls (industrial-chemical) } \\
\hline & $\begin{array}{l}\text { Exposure time, } \\
\text { years }\end{array}$ & $\begin{array}{c}\text { Specimen surface } \\
\text { evaluation }\end{array}$ & $\begin{array}{l}\text { Exposure time, } \\
\text { years }\end{array}$ & $\begin{array}{c}\text { Specimen surface } \\
\text { evaluation }\end{array}$ \\
\hline 302 & 5 & Free from rust stains & $<2 / 3$ & Rust stains \\
\hline 302 & 26 & Free from rust stains & & \\
\hline 304 & 26 & Free from rust stains & $<1$ & Rust stains \\
\hline 304 & & & 6 & $\begin{array}{l}\text { Covered with rust } \\
\text { spots and pitted }\end{array}$ \\
\hline 316 & 23 & Free from rust stains & $<2 / 3$ & Slight stains \\
\hline 316 & & & 6 & $\begin{array}{l}\text { Slight rust spots, } \\
\text { slightly pitted }\end{array}$ \\
\hline 317 & & & $<2 / 3$ & Slight stains \\
\hline
\end{tabular}

(a) Solution-annealed sheet, $1.6 \mathrm{~mm}$ (1/16 in. ) thick

(b) Pitting depths were not reported 


\section{WSRC INTERNAL DISTRIBUTION}

E. K. Opperman, 773-54A

R. J. Gromada, 773-53A

M. N. Van Alstine, 773-53A

M. W. Barlow, 104-K

D. H. Poss, 707-C

D. P. Eisele, 705-K

T. D. Woodsmall, 707-C

A. J. Cappucci, 707-C

C. R. Wolfe, 773-A

A. M. Murray, 773-A

T. L. Capeletti, 773-41A

N. C. Iyer, 773-A

R. L. Bickford, 730-A

R. L. Sindelar, 773-41A

T. E. Skidmore, 730-A

W. D. Daugherty, 730-A

C. F. Jenkins, 730-A

L. Hillary, 773-41A

SRTC Records, 773-52A 